\title{
The Conceptualization of Constitutional Supremacy: Global Discourse and Legal Tradition
}

\author{
Graziella Romeo*
}

(Received 30 June 2019; revised 17 November 2019; accepted 20 November 2019)

\begin{abstract}
This Article argues that a) constitutional supremacy is affected by the legal tradition, which implies that it is a concept largely shaped by the legal context in which it is elaborated, and b) the common law version of constitutional supremacy determines a sort of cultural resistance to constitutional imperialism. In making its argument, this Article begins with the doctrine of sources of law with a view to unpack its operational logic within the common law and, therefore, to understand how the supremacy of constitutions is conceptualized. It then examines the embryonic conceptualization of constitutional supremacy in the British legal culture by addressing the "constitutional statutes." It goes on to analyse how constitutional supremacy is safeguarded in jurisdictions that are affected by the British tradition and equipped with written constitutions, to show how constitutions concretely established themselves as supreme laws without neglecting the relevance of traditions pre-dating the constitutional texts. It then shows how the common law finds its way to be applied alongside or even instead of the constitution. Eventually, this Article offers some conclusions as to the implications of such a conceptualization of constitutional supremacy for comparative and global constitutional studies.
\end{abstract}

Keywords: Constitutional supremacy; constitutionalism; common law; constitutional adjudication; legal tradition

\section{A. Introduction}

The Enlightenment rationalist epistemology resonates in the practice of writing a constitutional document. Constitutions always express the idea that reality can be modelled according to a reasoned act of political will. ${ }^{1}$ One can argue that the Enlightenment trust in universal reason as capable of projecting an ordered policy may be traced back to the United States Constitution as well as to the Italian or German constitutional projects. ${ }^{2}$ All these constitutions claim to shape the legal order in their image because they incorporate values and principles that have been settled once and for all.

\footnotetext{
${ }^{*}$ Dr. Graziella Romeo is an Assistant Professor of Constitutional Law and member of the faculty for International Law and Economics at Bocconi University in Italy. She is a graduate in Law from Bocconi University and received her PhD in Constitutional Law from the University of Milan. And beginning on September 1, 2020, she will become an associate professor at Bocconi University. Additionally, she has been a visiting scholar and guest lecturer at Fordham Law School.

${ }^{1}$ Michael Oakeshott, Rationalism in Politics and Other Essays (1962). Alexander Hamilton referred to the Constitution as a project "of establishing a good government from reflection and choice." THE FEDERALIST No. 1 (Alexander Hamilton).

${ }^{2}$ As a matter of fact, any foundation of general norms capable of trumping particular statutes has been historically justified with an appeal to universal reason. See David Ibbetson, The Arguments in Calvin's Case (1608), in STUdIES IN CANON LAW and Common Law in Honor of R.H. Helmholz 222 (2015).
}

(C) The Author(s), 2020. Published by Cambridge University Press on behalf of the German Law Journal. This is an Open Access article, distributed under the terms of the Creative Commons Attribution licence (http://creativecommons.org/licenses/by/4.0/), which permits unrestricted re-use, distribution, and reproduction in any medium, provided the original work is properly cited. 
Written constitutions, however, do not always claim to be all-powerful in their own polity or to shape any relationship of legal significance. For instance, the horizontal effect of fundamental rights is consistent with the German Constitution while generally problematic under the US or Australian constitutional framework. Moreover, customary and written laws of constitutional relevance pre-dating the constitution can be included as sources of law in Canada or Australia, while these sources are completely irrelevant in Italian constitutional practice.

The "normativity" of the constitution, in other words, the constitution's ambition to shape the legal order and its institutions, is then to be separated from the "all-powerfulness" of the constitution. The latter can be identified with constitution's aim to expand its power as to solve any legal and political conflict and to reach any social behavior of legal significance. ${ }^{3}$ The normativity of the constitution translates into its all-powerfulness via a certain conceptualization of constitutional supremacy. The concept of constitutional supremacy describes constitutions' ability to establish a hierarchical primacy within the sources of law. This is to say that constitutional supremacy entails that the constitution trumps any other norm into the legal system in case of open conflict and/or conditions the interpretation of other norms that show some sort of inconsistency with constitutional imperatives. The latter point highlights the fact that the principle of supremacy does not only affect the rank order of legal norms, but also the institutional structure of the state because the supremacy of the constitution also entails the subordination of the legislator. ${ }^{4}$ So, in terms of legal thinking, the conceptual device of constitutional supremacy is able to transform the normativity of the constitution into all-powerfulness. ${ }^{5}$

Now, "constitutional imperialism" is a worldwide phenomenon in many democratic states because contemporary constitutions are able to provide answers to a large number of legal and political issues. ${ }^{6}$ If one looks at constitutional practice, however, it appears that such a kind of constitutional imperialism encounters some form of resistance in common law legal culture. Three examples can be provided: a) constitutions coexist with a large body of customary law of constitutional relevance as well as with statutory law of constitutional significance; b) the common law is increasingly occupying spaces that generally belong to constitutional law, such as fundamental rights; and finally, c) constitutional law tends to ignore relationships between private parties. Therefore, constitutional supremacy does not always ease the path from the normativity of the constitution to its all-powerfulness.

Against this backdrop, this Article argues that a) constitutional supremacy is affected by the legal tradition, which implies that it is a concept largely shaped by the legal context in which it is elaborated and b) a certain common law version of constitutional supremacy determines a sort of cultural and legal resistance to constitutional imperialism. ${ }^{7}$

\footnotetext{
${ }^{3}$ See Martin Loughlin, The Contemporary Crisis of Constitutional Democracy, 39 OxFord J. LEG. STUD. 435 (2019); Mattias Kumm, Who's Afraid of the Total Constitution? Constitutional Rights as Principles and the Constitutionalization of Private Law, 7 German L.J. 341 (2006).

${ }^{4}$ Jutta Limbach, The Concept of the Supremacy of the Constitution, 64 MoD. L. REv. 1, 7 (2001).

${ }^{5}$ Donald P. Kommers \& Russell A. Miller, The Constitutional Jurisprudence of the Federal Republic of GERMANY 47 (Durham and London eds., 2012). The authors argue that German constitutional scholars often insist on the strict enforcement of the Basic Law in all its particulars, "for to do otherwise would be to let the society become lawless." The authors further argue that in German public mind and legal scholarship the normativity of the Constitution needs to go hand in hand with the political realty. On the contrary, in the American legal mind "the written constitution is far from coextensive with American polity." This point is also emphasized by Limbach, supra note 4, at 7, who argues that the job of the Federal Constitutional Court "is to tie policy to law, and subordinate it to law." The author also identifies the relationship between the law-making power and the judicial review as the key problem the concept of supremacy of the constitution brings about.

${ }^{6}$ Bruce Ackerman, The Rise of World Constitutionalism, 83 VA. L. REv. 771, 798 (1997).

${ }^{7}$ The claim does not imply that every common law jurisdiction, just because of its belonging to this particular legal family, necessarily expresses a resistance to constitutional imperialism. There may be other factors contributing to the shaping of constitutional discourse and practice. One can argue that there are remarkable exceptions to a more generalized claim about the systematic impact of common law tradition on constitutional discourse. For example, in South Africa the "imperialism" of
} 
In making its argument, this Article begins with the doctrine of sources of law with a view to unpack the operational logic within the common law and, therefore, to understand how the supremacy of constitutions is conceptualised. This Article then examines the embryonic conceptualization of constitutional supremacy in the British system by addressing the "constitutional statutes". It goes on to analyze how constitutional supremacy is safeguarded in jurisdictions that are affected by the British tradition and equipped with written constitutions, to show how constitutions concretely established themselves as supreme laws without eliminating legal traditions pre-dating the constitutions. It then shows how the common law finds its way to be applied alongside or even instead of the constitution. Eventually, this Article offers concluding remarks as to the implications of such a conceptualization of constitutional supremacy for comparative and global constitutional studies. Indeed, understanding the supremacy claim of constitutions helps clarify the difference between entrenching a certain constitutionally oriented legal interpretation into the legal tradition and identifying the latter as a self-sufficient reservoir of solutions that is capable of providing an answer in a perfect isolation from external-either international or foreign-sources.

This Article uses the concepts of legal tradition and, at times, legal culture with a view to underline the relevance of the legal context in which the conceptualization of constitutional supremacy occurs. Comparative law has devoted much attention to those concepts. ${ }^{8}$ They are used here to refer to the way in which lawyers frame legal concepts by borrowing from the past and by relying on a culturally and historically conditioned understanding of those concepts. This Article mentions examples from five common law jurisdictions: The UK, Australia, Canada, Ireland, and the United States. Such selection needs some clarification. Indeed, these countries express different examples of commitment to constitutionalism. The UK has an uncodified constitution. Within the Commonwealth countries, only Canada has an entrenched bill of rights, while Australia has no bill of rights. ${ }^{9}$ The United States developed constitutional theory of law before the concept of constitutional supremacy reached any other place. Ireland has both a constitution and a system of judicial review established by it. Both the United States and Ireland have been included in the present analysis because, as it will be argued in more detail below, the common law legal tradition exerts an influence in shaping constitutional discourse.

Thus, by referring to those jurisdictions, this Article intentionally overlooks the taxonomies of common law constitutionalism, which, for example, distinguish between Commonwealth and

\footnotetext{
the Constitution was able to significantly affect the horizontality of fundamental rights. Precisely for the peculiar context of its constitutional experience, characterized by the need to overcome the past, South Africa is not included in the present analysis.

${ }^{8}$ See, e.g., John H. Merryman, On Convergence (and Divergence) of the Civil Law and the Common Law, 17 STAN. J. INT'L L. 357, 381 (1981). Merryman coined the term "cultural gravity" to refer to how "those historically conditioned, deeply rooted attitudes about the nature of law and about the proper structure and operation of a legal system that are at large in the society" affects the operation of legal systems. The author also used the term "legal tradition" to refer to culturally conditioned attitudes that underlie legal rules and also to ideas about the role of law in the organization of the political community, in society and in international relations. J.H. Merryman, The Civil LAw Tradition: An Introduction to the Legal Systems of Western EUROPE AND LATIN AMERICA 2 (1985). Nelken describes legal culture "as one way of describing relatively stable patterns of legally-oriented social behaviour and attitudes. The identifying elements of legal culture range from facts about institutions such as the number and role of lawyers or the ways judges are appointed and controlled, to various forms of behaviour such as litigation or prison rates, and, at the other extreme, more nebulous aspects of ideas, values, aspirations and mentalities." David Nelken, Using the Concept of Legal Culture, 29 AusTL. J. LEG. PHIL. 1 (2004). Glenn uses the locution "legal tradition" in more detailed fashion as an epistemological tool that is capable of explaining the developments of a legal system. PATRICK GLENN, Legal Traditions of THE WorLd (5th ed. 2005). Both Glenn and Watson discuss the interplay between legal culture and legal tradition with a view to clarify how the two locutions need to be differentiated as to preserve the distinctiveness of the term legal tradition as being able to explain the relevance of both the pastness and the transmission of information. Alan Watson, Legal Culture v. Legal Tradition, in Epistemology and Methodology of Comparative Law 2 (Mark Van Hoecke ed., 2004); H. Patrick Glenn, Legal Cultures and Legal Traditions, in Epistemology and Methodology of Comparative LAW 11-12 (2004).
}

${ }^{9} \mathrm{New}$ Zealand has not been included, as their constitution is a flexible one. 
American constitutionalism. ${ }^{10}$ This choice is not intended to underestimate the differences between forms of common law constitutionalism, but rather to point to the continuity of some elements in constitutional discourse within the common law, understood as legal family. Indeed, despite the fact that the common law diversified internally, comparative lawyers still identify a unified legal tradition of common law, mainly because of the endurance of some methodological approaches to law in all the countries that have been influenced by the English tradition. ${ }^{11}$ Adhering to such understanding of the common law, this Article strives to shape constitutional discourse in a legal tradition-centered fashion.

\section{B. The Place of Constitutions as "Supreme Laws"}

Various studies address the existence of a distinctive kind of constitutionalism in common law countries. Some of them focus on how the logic of common law makes it possible for written constitutions to be applied in a manner consistent with the theoretical framework of customary constitutional law. For example, American scholars have argued that the framers of the United States Constitution intended it to be interpreted in light of customary constitutional law. ${ }^{12}$ David Strauss coined the phrase "common law constitutional interpretation" to explain how the common law can be a method in constitutional interpretation. ${ }^{13}$ Others have noted the difference between American constitutionalism and Commonwealth constitutionalism with respect to the endurance of the British tradition of legislative supremacy in Commonwealth constitutional settings. ${ }^{14}$ The literature thus underlines the existence of common law constitutionalisms, and yet it is still mostly focused on how nearly constitutional experiences in common law countries approach the definitional model of written constitutions provided with a bill of rights and secured by a strong system of constitutional adjudication. After all, the term "constitution" has an essential uncontested core meaning, which implies some forms of limitation of powers for the sake of enjoyment of freedoms. ${ }^{15}$

Still, if one explores constitutional practice, it appears that such minimum area of agreement on the term "constitution" does not say much on how the supremacy of a fully-fledged constitutional text is actually secured. The deconstruction of the term "constitution" in some jurisdictions, as well as the hypertrophy of constitutional law in others, may leave scholars confused about the supremacy claim of written constitutions. Stephen Gardbaum addresses the issue in the Oxford Handbook of Comparative Constitutional Law. He underlines that the conventional distinction between big-c and small-c constitutionalism has become of little help to understand contemporary constitutional practice across different jurisdictions and legal traditions. ${ }^{16}$ According to Gardbaum, the limited explanatory power of such distinction is proved by many factors: The development of theories of unwritten constitutional law in countries such as the US; the creation of the category of constitutional statutes in the UK; the constitutionalization of international law; and, finally, the theory of the "total constitution" as an example of the needlessness of the distinction between constitutional law and other laws in a legal system. ${ }^{17}$

Such general trends or transformations possibly share the same roots, including globalization, supranational integration, and the success of human rights theories. Against this backdrop, as this

\footnotetext{
${ }^{10}$ Stephen Gardbaum, The New Commonwealth Model of Constitutionalism, 49 AM. J. Comp. L. 707 (2001).

${ }^{11}$ Patrick Glenn, Legal Traditions of the World: Sustainable Diversity in LaW 260-61 (5th ed. 2014).

${ }^{12}$ Eric Engle, Death Is Unconstitutional: How Capital Punishment Became Illegal in America - A Future History, 6 PIERCE L. REV. 485, 514 (2007).

${ }^{13}$ David A. Strauss, Common Law Constitutional Interpretation, 63 U. CHI. L. REV. 877 (1996).

${ }^{14}$ Gardbaum, supra note 10.

${ }^{15}$ Giovanni Sartori, Constitutionalism: A Preliminary Discussion, 56 AM. PoL. SCI. REv. 853 (1962).

${ }^{16}$ See Stephen Gardbaum, The Place of Constitutional Law in The Legal System, in OXFORD HANDBOOK OF COMPARATIVE Constitutional Law 167 (Michel Rosenfeld \& András Sajó eds., 2013).

${ }^{17} \mathrm{Id}$. at 170 .
} 
Article argues, the legal tradition plays a role in shaping constitutional discourse. So, irrespective of the most recent developments in constitutional practice at the global level, constitutional supremacy is differently conceptualized across jurisdictions.

Indeed, if a civil lawyer looks at how constitutional cases are framed in common law countries, he or she may verify that some expected implications of constitutional supremacy are not straightforward consequences in common law jurisdictions equipped with written constitutions. Implications that a civilian would expect are: a) The text is comprehensive, though it may need marginal integration from constitutional praxis or implementing legislation; $b$ ) the constitution is normative no matter how much it reflects a traditional legal ethos; and c) constitutional arguments are a ruling-out move in litigation, meaning that whenever a sound constitutional argument is introduced, it takes precedence on other arguments and needs to be addressed by the judge in the case. ${ }^{18}$ If one takes a close look at constitutional practice in common law jurisdictions, one can easily realize that these three particular circumstances are not always verified. It can happen that: a) The constitution coexists with a large body of conventions and ordinary laws with constitutional status; b) the constitution interacts with a traditional legal ethos; and c) constitutional arguments can be easily avoided in litigation. These differences rest on constitutional history, as far as a) and b) are concerned, and on the structure of constitutional adjudication, as far as c) is concerned. They need, however, to be further explored to understand how constitutions are indeed supreme laws of the land without claiming to overtake the traditional legal ethos.

Here is where the sources of law, the legal bases lawyers would consider authoritative to justify or require conduct, come into play.

In countries where there is a written constitution and an entrenched bill of rights, as in Canada, as well as in countries where the constitution is partially codified, as in Australia, the constitutional nature of a source of law does not exclusively derive from its nomen. ${ }^{19}$ Rather, it depends on the ability of that source to substantially express certain essential characteristics generally ascribed to the category of constitutional sources. Therefore, understanding how and to what extent constitutional sources distinguish themselves from other sources of law, both in terms of formal hierarchy and in terms of their normativity, requires addressing the internal logic of the doctrine of sources of law in the common law tradition.

A general premise is needed: If one looks for the formally ordered hierarchical theory of sources of law in civil law systems, one may well be disappointed. In fact, a Kelsenian Stufenbau (step by step construction) does not have a precise homologue in the common law tradition, ${ }^{20}$ including in those countries in which written constitutions explicitly declare the constitution to be the supreme

\footnotetext{
${ }^{18} \mathrm{As}$ far as point $\mathrm{b}$ ) is concerned, it must be stressed that the persistence of elements of the legal tradition is visible to some extent in civil law countries as well, especially as far as judicial reasoning is concerned. One can name the example of Germany, where the conceptualization of the relationship between the Constitution and the polity owes something to the notion of Rechtsstaat that conceived the polity as a juristic construction. The contemporary understating of the unity of the constitution in terms of its ability to influence political practice is to be traced back to the legal tradition of the Rechtsstaat according to KOMMERS \& Miller, supra note 5, at 47. Moreover, the concept of supremacy of the Constitution started to be elaborated before the enactment of the Basic Law. Indeed, during the German Empire of 1871, the right of judicial review progressively extended from the question of the legitimacy of the monarch's power to issue ordinances to the question whether such a power was compatible, as far as the content of the ordinances was concerned, with the constitution and other laws of higher rank. See Werner Heun, Supremacy of the Constitution, Separation of Powers, and Judicial Review in Nineteenth-Century German Constitutionalism, 16 RATIO JURIS 195, 199 (2003). The author further stresses that such a change in the exercise of judicial review also affected the structure of the state by curtailing the Emperor's autonomous power to enact ordinances without a parliamentary authorization or at least consent.

${ }^{19}$ One has to be careful, however, as not to overestimate differences between civilians' and common lawyers' legal minds. Even in civil law countries some constitutional developments such as supranational integration processes have affected both the system of sources of law and its conceptualization by scholars. Marta Cartabia, Le Sentenze "Gemelle:" Diritti Fondamentali, Fonti, Giudici, GiURISPRUdenZa CostituZIONALE, 2007, at 3565-66.

${ }^{20}$ Hans Kelsen, Allgemeine Theorie Der Normen (Kurt Ringhofer \& Robert Walter eds., 1979). See also Stanley L. Paulson, Book Review, 27 AM. J. JuRIs. 159, 162 (1982) (reviewing Kelsen's and German scholars' works).
} 
law of the land. ${ }^{21}$ Moreover, the sources of law have not been the object of many theoretical studies in the field of constitutional law, remaining a neglected subject for common lawyers. ${ }^{22}$ Indeed, in British, Australian, and Canadian constitutional law textbooks, for example, there may be systematic classifications of sources of law, while a broad theoretical construction is generally missing. ${ }^{23}$ Such an approach reveals common lawyers' predilection for a conception of law as argumentative practice based on formal rules that determine the validity and the scientific rigor of legal arguments and yet largely developed as practical discourse rather than as the fulfilment of a precise theoretical and dogmatic construction. ${ }^{24}$

The absence of a Kelsenian Stufenbau, however, does not imply that a hierarchy of sources of law does not exist. Rather, it implies that hierarchy comes with an inherent flexibility.

The traditional English doctrine organizes legal materials in a hierarchical order, distinguishing between legislation, precedents, customs, and agreements. ${ }^{25}$ Contemporary British lawyers use the same matrix, but they add international sources-both from the EU, which will no longer be the case, and from the ECHR-and the Constitution, broadly understood. ${ }^{26}$ Common lawyers from other jurisdictions organize legal materials according to a hierarchy that starts with the written constitution, goes on with international sources-which are generally incorporated through statutes and thus made equal to legislation-and then proceeds with legislation, precedents, and customs.

The hierarchical principle is always activated in cases of conflict between sources, but not necessarily when it comes to the identification of the legal rule governing a case. In fact, litigation is largely governed by the argumentative choices of the parties. It means that the identification of the source of law governing the concrete case depends on how parties introduce the arguments in a lawsuit. Within this context, judges can easily avoid, if they want to, questioning the hierarchy of the source to be applied in the controversy. ${ }^{27}$

Ultimately, the lack of a Stufenbau means that the selection of applicable law, including sources of constitutional rank, is regulated according to a logic that has little, if anything, to do with both the metalegal foundation of the legal system - the Grundnorm - and a conditional concept of validity. This is not to say that a Grundnorm is not identifiable in abstract. Rather, it means such Grundnorm does not work as a theoretical criterion of selection of the applicable sources, nor does it create the need for judicial review on the validity of legislation. Therefore, the hierarchy

\footnotetext{
${ }^{21}$ Such a clause is included in all the written constitutions of the common law countries analyzed here: Article VI, US Constitution ("This Constitution, and the laws of the United States which shall be made in pursuance, and be treaties made, or shall be made under the authority of the United States, shall be the supreme law of the land."); Article 52, Canadian Constitution ("The Constitution of Canada is the supreme law of Canada, and any law that is inconsistent with the provisions of the Constitution is to the extent of the inconstancy, of no force or effect."); and Article 5 Commonwealth of Australia Constitution Act ("This Act, and all laws made by the Parliament of the Commonwealth under the Constitution, shall be binding on the courts, judges, and people of every State and of every part of the Commonwealth, notwithstanding anything in the laws of any State.").

${ }^{22}$ British scholars concede that theoretical contributions on the issue of sources of law are quantitatively limited and generally unclear. The sources of law are pragmatically defined as sources that lawyers invoke to justify their decisions as "appeal to the best interpretation of what the legal community accepts as the reference points for correct legal argument in the particular area of the law." John Bell, Source of Law, 77 CAMBRIDGE L.J. 40, 40-41 (2018).

${ }^{23}$ William R. Lederman, Classification of Laws and the British North America Act, in The Courts and THE CANADIAN Constitution 177 (William R. Lederman ed., 1964).

${ }^{24}$ Lord Neuberger has vividly depicted common lawyers as industrious bees and civil lawyers as spiders "developing intricate, principle-based codes, which can be logically and rigidly applied to all disputes." See David Neuberger, Developing Equity - A View From the Court of Appeal, Chancery Bar Association Conference 2012 (Jan. 20, 2012), https://www.judiciary.uk/wpcontent/uploads/JCO/Documents/Speeches/mr-speech-chancery-bar-assoc-lecture-jan12.pdf.

${ }^{25}$ John W. SAlmond, JURISPRUdENCE 168 (7th ed. 1924).

${ }^{26}$ John Bell, Sources of Law, in English Private Law 4 (Andrew Burrows ed., 3d ed. 2013).

${ }^{27}$ Cesare Cavallini, Why Is the iura novit curia Principle Not Applied Yet in English Law?, 17 GLOBAL JuRIST 1, 3 (2017). Parties, however, are not completely free to identify applicable law, because they are of course bound by professional rules of ethics.
} 
does not serve the purpose of establishing the normativity of a source in its compliance with the principles of another hierarchically superior norm that dictates the conditions of validity of the inferior norm. There is thus no relationship of conditionality, in principle, between a hierarchically superior source and one that is inferior: The validity of the hierarchical inferior norm does not depend on its correspondence to substantive principles of the superior norm. Therefore, the hierarchy assumes a practical value for the solution of normative conflicts.

The theoretical backdrop of this approach matches with the principle of parliamentary sovereignty. Only when the Parliament has legislated on a certain matter are the precedents and the common law rules no longer applicable. Yet this does not necessarily have consequences in terms of validity of both the precedents and the common law. By contrast, invalidity occurs if a statute authorizes the enactment of secondary legislation. In this case, there is a relationship of conditionality between the two sources, such that the repeal of the legislative source also overtakes secondary legislative acts.

Such a framework concerning the functioning of the sources of law has been partially affected by written constitutions. When observed from the perspective of constitutional sources, however, this approach explains that constitutional supremacy does not in principle affect the validity of legislative acts which are in substantial contrast to the constitutional source, as it would be under Kelsenian doctrine. This is the reason why constitutional supremacy can be theoretically combined with some forms of legislative supremacy. Indeed, judicial review, even when it determines the annulment of legislation, has been almost everywhere justified after the establishment of constitutions and, therefore, in principle it is not immediately linked to the concept of constitutional rigidity. Courts have created such a link when they have eventually had to justify the power of constitutional adjudication.

The clearest and foremost example is the US Supreme Court welding together constitutional rigidity and judicial review of legislation in the well-known decision Marbury v. Madison, ${ }^{28}$ where the Court held that ensuring the effectiveness of the Constitution as supreme law of the land implies that the Court should have the power to strike down legislative acts that are in conflict with constitutional provisions.

The Court resorted to the English legal tradition, namely to Sir Coke's doctrine, elaborated in the decision Bonham's Case. ${ }^{29}$ Coke's arguments about circumstances in which courts may hold acts of Parliament that are against common reason void ${ }^{30}$ have been dropped in the context of a written constitution. Therefore, their jus naturalistic echo has been translated into an argument that rests on a solid basis of formal-legal logic. The argument, however, does not build a theoretical structure that binds together constitutional rigidity and judicial review of legislation with a more general hierarchy of sources of law, ordered according to relations of conditional validity. After all, the problem that the US Supreme Court intended to solve in that particular case was the protection of fundamental rights in an impartial way, with a view to preventing the dissolution of the original compact created by the signing of the federal Constitution. Indeed, Marbury v. Madison raised a right-based and remedy-oriented question.

Ultimately, the doctrine of the constitution as higher law coexists with a legal tradition that does not intend to systematize the sources of law according to a theoretical criterion for selection of the most legitimate source controlling the solution of the concrete case. Such approach makes it concretely possible for judges: a) To decide whether to frame an issue in constitutional terms or

\footnotetext{
${ }^{28}$ Marbury v. Madison, 5 U.S. 137 (1803).

${ }^{29}$ Thomas Bonham v. College of Physicians (1610) 77 Eng. Rep. 638, 646. See also William M. Treanor, The Case of the Prisoners and the Origins of Judicial Review, 143 U. PENN. L. ReV. 491 (1994) (analyzing the influence of Sir Coke's doctrine on the development of constitutional law in the US).

${ }^{30}$ College of Physicians, 77 Eng. Rep. at 8. Co. Rep. 107a (" $[\mathrm{W}]$ hen an Act of Parliament is against common right and reason, or repugnant, or impossible to be performed, the common law will control it, and adjudge such Act to be void.”). See also Charles M. Gray, Bonham's Case Reviewed, 116 Proc. AM. PhiL. Soc’y 1, 35-58 (1972).
} 
not; and b) to interpret constitutional provisions in light of non-constitutional norms without undermining the normativity of the written text.

So the hierarchy of the sources of law is theoretically compatible with the idea that: a) The constitution can be subsidised by other sources of law-precedents and common law-in constitutional argumentation, and b) those sources can take over the constitution under certain circumstances.

With a view to explain how the common law legal tradition resonates in constitutional discourse, it is proper to briefly address how constitutional supremacy is framed within the British system.

\section{Is There Something Like "Constitutional Supremacy" in the British Tradition?}

The codification of constitutional law in the Commonwealth determined the progressive estrangement of common law countries from the British tradition of unwritten constitutional law, entrusted with the care of the political culture. ${ }^{31}$

In parallel, both the spread of constitutional discourse and the processes of supranational integration have led British scholars and judges to question the foundation of the British model as far as both the structure of the system of sources of law and the development of constitutional law are concerned. ${ }^{32}$ Examining this shift in the British system offers insight into how an unwritten and customary constitution is challenged, and yet not won, by arguments supporting the need to single out some laws and norms as paramount to the whole system. The purpose is to identify some of the arguments resonating in other common law countries' constitutional discourse.

Defining the British uncodified constitution is not an easy task. In the absence of codification, alternative accounts of what the constitution is coexist. Some scholars describe it in terms of the specific arrangement of powers resulting from historical experience and documents, while others suggest that the constitution expresses a fixed set of normative principles. ${ }^{33}$ The very need to frame British constitutional discourse in the form of an-albeit uncodified-constitution is contested by some scholars. Political constitutionalists, for example, either suggest that British constitutional practice was mostly forged by political choices rather than by normative principles, whether codified or not, or provide a normative framework according to which any form of legal supremacy of any law or substantive value would endanger the democratic ideal of political equality. ${ }^{34}$

For the purpose of the present study, it is not necessary to delve into the broader issue of the contents of the British constitution. Rather, this Article focuses on the conceptualization of hierarchical supremacy of some pieces of ordinary legislation implying that constitutional supremacy may have a place in British constitutional discourse. The recent proliferation of legislation to which some sort of constitutional status is attached suggests this may be a way of exploring the significance of constitutional supremacy. Indeed, from 1997 onwards, the UK experienced a series of constitutional reforms, concerning both the protection of rights and the organisation of infra-state powers. As a consequence, the Parliament randomly used the word "constitutional"

\footnotetext{
${ }^{31}$ See Political Culture and Political Development 7-8 (Lucian W. Pye \& Sydney Verba eds., 1965).

${ }^{32}$ John W.F. Allison, English Historical Constitution: Continuity, Change and European EfFects 10 (2007). The author criticizes in particular Dicey's theory, focused on the immutability of the principle of parliamentary sovereignty, which Dicey believed to be able to unveil "the peculiar genius of existing English Constitution."

${ }^{33}$ Robert B. Taylor, The Contested Constitution: An Analysis of the Competing Models of British Constitutionalism, PuB. L. 500 (2018); Martin Loughlin, The British Constitution 19 (2013) (discussing the traditional and the modern idea of constitution); Trevor R.S. Allan, Law, Liberty And Justice: The Legal Foundations Of British Constitutionalism (1993).

${ }^{34}$ Reference is made to the works of John A.G. Griffith, The Political Constitution, 42 Mod. L. Rev. 1 (1979); AdAM Tomkins, Our Republican Constitution (Hart ed., 2005); Thomas Poole, Tilting at Windmills? Truth and Illusion in "The Political Constitution," 70 Mod. L. Rev. 250 (2007); Richard Bellamy, Political Constitutionalism (2009).
} 
to identify some defining features of the new British system. ${ }^{35}$ It was the judiciary that started to make sense of some fundamental changes in powers arrangements by elaborating the category of constitutional statutes. Constitutional statutes are laws approved by ordinary procedure, but with substantially constitutional content. Such statutes are endowed with a peculiar force of resistance to repeal by succeeding legislative acts, even though they share the same formal characteristics as ordinary legislation.

An ordinary law's inclusion into the category of constitutional statutes has been mainly a judicial choice, as there is no ad hoc legislative procedure for such statutes. Yet, as the process of exiting the European Union is showing, the Parliament may adopt special procedures in consideration of the constitutional character of the legislation that it intends to pass. ${ }^{36}$

The Miller judgement, which involved the constitutional requirement to trigger Article 50 TEU in order to exit the EU, clarified the meaning of constitutional statutes-also named as acts of "particular legal importance"-by addressing the need for parliamentary express repeal of the European Community Act 1972 (ECA). ${ }^{37}$ Even before the Miller judgement, a long series of judicial decisions qualified the ECA and other sources as substantively constitutional. ${ }^{38}$ Indeed, courts at the apex of the judicial system recognized the constitutional nature of the Petition of Rights of 1628, Bill of Rights of 1689, Act of Settlement of 1701, Representation of People Acts of 1832-84, Human Rights Act of 1998, the Scotland Act of 1998, Northern Ireland Act of 1998, Constitutional Reform Act of 2005, and Government of Wales Act of $2006 .{ }^{39}$

Lord Justice Laws identified two elements that make a statute constitutional: a) The ability to significantly influence the relationship between state and citizens; and b) the ability to extend or reduce the scope of fundamental rights. ${ }^{40}$

Given the lack of a formalized hierarchy between constitutional statutes and ordinary statutes, consequences of the constitutional nature of the former type are visible only when courts apply statutes qualified as constitutional. At the same time, consequences vary depending upon the content of the constitutional source and, to a not insignificant extent, upon judges' sensitivity.

By looking at the case law, one can argue that constitutional statutes interact with ordinary statutes in three ways. First, constitutional statutes determine the rejection of the rule of implied repeal, whereby when Parliament adopts a law that is in conflict with a previous text, it must be assumed that Parliament implicitly intended to repeal the former law. The exception to the rule of implied repeal means that a constitutional statute can be repealed only when Parliament explicitly intends to produce such an effect. In the decision $B H v$. Lord Advocate, ${ }^{41}$ Lord Hope writes, for a

\footnotetext{
${ }^{35}$ See, e.g., Constitutional Reform Act 2005, $\$ 1$ (Eng.).

${ }^{36}$ Select Committee on the Constitution, European Union (Withdrawal) Bill: Interim Report, 2017-19, HL (UK),https://publications.parliament.uk/pa/ld201719/ldselect/ldconst/19/1906.htm.

${ }^{37} \mathrm{R}$ (Miller) v. Sec'y of State for Exiting the European Union [2017] UKSC 5.

${ }^{38}$ See: McWhirter v. Sec'y of State for Foreign \& Commonwealth Affairs [2003] EWCA Civ 384; R (Buckinghamshire Cty. Council) v. Sec'y of State for Transport [2014] UKSC 3, [2014] 1 WLR 324; R (HS2 Action Alliance Ltd.) v. Sec'y of State for Transport [2014] UKSC 3, 207; Thoburn v. Sunderland City Council [2002] EWHC 195 (Admin).

${ }^{39}$ See Thoburn, [2002] EWHC 195. The Political and Constitutional Reform Committee, gathered to study the possibility of codifying constitutional sources of law, has also included in the list the Parliament Acts of 1911 and 1949 and the Life Peerages Act of 1958. Andrew Blick, Codifying-or Not Codifying—-THe United Kingdom Constitution: The Existing CONSTITUTION (2012), https://www.parliament.uk/documents/commons-committees/political-and-constitutional-reform/ KCLexistingconstitutionMay2012.pdf. In the book Constitutions of the Countries of the World, Blaunstein and Flanz also include the Government of Ireland Act of 1920, the Crown Proceedings Act of 1947, the Race Relation Act of 1976, and the British Nationality Act of 1981. See the chapter dedicated to the United Kingdom in Albert P. BlaunsteIN, Constitutions Of The Countries Of The World 43 (Gisbert H. Flanz ed., 2013). Finally, according to some scholars, the Magna Carta is a "constitutional instrument" because it was not adopted as a statute in the first place: see MARY Arden, Common Law and Modern Society: Keeping Peace With Change 108 (2015) who also discusses the constitutional meaning of Magna Carta in contemporary British Constitution.

${ }^{40}$ Thoburn, [2002] EWHC 195. See also John Laws, The Common LaW Constitution (2014).

${ }^{41} \mathrm{BH}$ and Another v. The Lord Advocate and Another [2012] UKSC 24, [2013] 1 AC 413 [30].
} 
unanimous court, that the Scotland Act of 1998 is "incapable of being altered otherwise than by an express enactment." 42

Second, constitutional statutes enjoy a strengthened presumption of consistency. In cases of conflict between a substantially constitutional statute and an ordinary statute, courts have to interpret the latter in a manner consistent with the former or, when it is not possible, they give precedence to a legal solution that preserves the constitutional statute. ${ }^{43}$

Third, the constitutional nature of a statute determines the exclusion of the speciality rule every time the consequence is the non-application of the substantively constitutional source. For example, in the Brynmawr case, ${ }^{44}$ concerning a conflict between the Government of Wales Act of 2006 (GOWA) and the School Standards and Framework Act of 1998, the Supreme Court clarified that the latter, although lex specialis, could not determine the non-application of GOWA because of its constitutional nature.

The Supreme Court's hierarchy of sources in which constitutional statutes are set apart from other parliamentary statutes may correspond to an attempt to establish some form of constitutional supremacy. ${ }^{45}$ It is, however, a controversial choice.

It has been challenged by scholars who point out inconsistencies in the Supreme Court's understanding of the nature of such statutes. ${ }^{46}$ It has also been questioned for being an incomplete definition. Indeed, some scholars underlined other relevant features of constitutional statutes, such as the ability to influence the exercise of powers or the ability to determine the conditions of validity of other norms in the legal system. ${ }^{47}$ Others argue instead that the constitutional nature of a statute depends on its ability to affect four basic elements of the British constitution: The rule of law, the principle of parliamentary supremacy, the relations between Government and Parliament, and, finally, the vertical division of powers. ${ }^{48}$

In any case, this tentative hierarchy does not seem to correspond to a settled understanding of the theory and practice of sources of law under the British constitution. This lack of consensus in the legal community is visible in scholarly debates, and it also resonates in judicial practice. In fact, one can verify that the constitutional nature of a statute does not necessarily make it paramount to other statutes and, most importantly, to the common law. For example, in the Anufrijeva ruling, ${ }^{49}$ the House of Lords made it clear that the fundamental rights protected in the legal system extend far beyond the provisions of the European Convention on Human Rights and correspond to the historical guarantees of common law, as well as to those deriving from other international human rights conventions. These guarantees are considered to be equivalent if not superior to those protected under the Human Rights Act of 1998. This understanding has been named common law constitutionalism, as it derives rights directly from the common law and it supports the

\footnotetext{
${ }^{42} I d$.

${ }^{43}$ This is the case with the Human Rights Act of 1998, which incorporates the ECHR into the British legal system. See Regina v. Dir. of Pub. Prosecutions Ex Parte Kebeline \& Others [1999] 4 AII ER 801 (particularly Lord Hope's statement that "[i]t is now plain that the incorporation of the ECHR into our domestic law will subject the entire legal system to a fundamental process of review and, where necessary, reform by the judiciary").

${ }^{44} \mathrm{R}$ (Governors of Brynmawr Foundational Sch.) v. The Welsh Ministers (Brynmawr) [2011] EWHC 519.

${ }^{45}$ After all, Lord Laws, when sitting at the Court of Appeal, stated that the British system in its present state of evolution "may be said to stand at an intermediate stage between parliamentary supremacy and constitutional supremacy." Int'l Transport Roth GmbH v. Sec'y of State for the Home Dep't [2002] EWCA Civ 158.

${ }^{46}$ Tarun Khaitan, How to Interpret Constitutional Statutes?, UK ConstitUTIONAL LAW Blog (Jan. 12, 2012), https:// ukconstitutionallaw.org/2012/01/10/tarun-khaitan-how-to-interpret-constitutional-statutes/.

${ }^{47}$ This is, for example, the argument made by Farrah Ahmed \& Adam Perry, Constitutional Statutes, 37 OXFORD J. LEGAL STUD. 461, 471 (2017).

${ }^{48}$ Mark Elliott \& Stephen Tierney, Political Pragmatism and Constitutional Principles: The European Union (Withdrawal) Act 2018, Pub L. 37 (2019).

${ }^{49}$ R. (Anufijeva) v. Sec'y of State for the Home Dep't [2003] UKHL 36, [2004] AC 604, 27. See also Lord Steyn and R (Q) v. Sec'y of State for the Home Dep't [2003] EWCA Civ 364, [2004] QB 36, 115.
} 
unnecessariness of the entrenchment of fundamental rights. ${ }^{50}$ So, common law constitutionalism, which is one of the competing narratives of British constitutionalism, is not necessarily compatible with the idea of the constitutional nature of some statutes. Indeed, it theoretically authorizes courts to develop a human rights law in a way that departs from the Human Rights Act, a statute that has been defined as constitutional.

With the caveat associated to a moment of profound transformation in the British constitution, and more broadly, in British constitutional law, there is room to conclude that "constitution" and "constitutional law" are still content-specific terms. Indeed, the constitutional nature of a norm rests on its content more than on its formal characteristics or on the legal consequences that it is able to determine on other sources of law in the legal system.

This is a conceptual bequest that still has a grip on the development of constitutional discourse in other common law countries, as the next two sections will argue in more details.

\section{Constitutional Supremacy in the Context of Common Law Written Constitutions}

Within common law constitutional experiences, constitutional supremacy, rigidity, and judicial review are not contextually established under the constitution. Rather, the logical link between a) constitutional supremacy, b) constitutional rigidity, and c) judicial review is established ex post. Such a framework helps consolidate a legal practice in which the constitution is at the same time supreme and open to be subsidised by the legal tradition. As a result, the supremacy of constitutions is grounded in the constitutions' ability to preserve historically entrenched and successfully tested legal solutions. Moreover, constitutional supremacy is in principle compatible with some sort of legislative supremacy in matters that do not interfere with constitutional mandates.

For example, in Australia, the written Constitution does not establish a complete system of fundamental values and principles that permeate the whole legal order. Though the Constitution contains some specific individual freedoms, ${ }^{51}$ the frame of government is not designed to ensure a system of explicitly entrenched fundamental rights. As a consequence, the normativity of the written constitution is based on two separate, yet related, assumptions: That constitutional supremacy does not rule out legislative supremacy and that the common law provides for the recognition of fundamental rights.

Recalling elements of Australian constitutional history can help to explain how legislative supremacy and a lack of fundamental rights come to coexist with a constitution that is recognised as the supreme law of the land. The Australian Constitution was adopted in 1900 as an act of the Westminster Parliament ${ }^{52}$ and came into effect the following year after a series of confirmatory referendums held in each Australian colony. ${ }^{53}$ The High Court was established under the Constitution as a court of appeal for decisions coming from both state and federal courts. The High Court claimed the power of judicial review almost immediately with the pivotal ruling Amalgamated Society of Engineers $v$. Adelaide Steamship, ${ }^{54}$ despite both the absence of an express constitutional provision and the lack of any foothold in the English legal tradition.

The Australian High Court draws its justification for the power of judicial review from the American constitutional experience. ${ }^{55}$ Nonetheless, the High Court's defence of judicial

\footnotetext{
${ }^{50}$ See R. Lord Chancellor, formerly Lightfoot [2005] QB 597 (Laws J) 609 B. Lord Laws defined such constitutional rights in terms of a "special class of rights which, in truth, everyone living in the rule of law ought to enjoy." Robert B. Taylor, supra note 33 , at 500 .

${ }^{51}$ See Australian Constitution ch IV s 92 (on commerce and trade), which was interpreted by the High Court as a guarantee of individual freedom of economic initiative and trade.

${ }^{52}$ Commonwealth of Australia Constitution Act, 1900.

${ }^{53}$ For a detailed history of the process behind the Australian Constitution, see John A. LA NAUze, The MakING Of The Australian Constitution (1972).

${ }^{54}$ Amalgamated Soc'y of Engineers $v$ Adelaide Steamship Co. Ltd. (1920) 28 CLR 129 (Austl.).

${ }^{55}$ Andrew I. Clark, Studies in Australian Constitutional Law 6 (6th ed. 2009) (discussing the relevance of US constitutional experience for Australian constitutional scholarship and practice).
} 
review is primarily based on the need to protect the federal principle vis-à-vis any interference from state legislative power. Indeed, the first cases of judicial review of legislation, adopted in the first decade of the twentieth century, concern claims about legislation passed at the state level. The most emblematic decisions are D'Emden v. Pedder and Wollaston. ${ }^{56}$ Both cases concerned the state power of taxation. In both cases, the High Court found that the exercise of this power on the part of the states had infringed upon federal legislative power that was expressly referred to as absolute and free from any interference except that prescribed by the constitution itself. By contrast, the Court did not insist much on the constitutional duty to curb the overflow of the legislative power in a more general manner.

Later on, the High Court clarified that the power of judicial review was "axiomatically" part of the Australian constitutional system. ${ }^{57}$ Such reasoning, however, does not simply mirror Marbury v. Madison. The Australian judges explained that the principle encapsulated in Marbury needs to be mitigated and adjusted to the Australian constitutional framework. The judges sought in the text of the Constitution the foundation for the power of judicial review. First, from Article 5, which expresses the obligation to legislate "under the Constitution," the High Court derived the obligation to verify the constitutionality of the product of legislative activity. ${ }^{58}$ Second, the Court also referred to Article 76(i), which gives Parliament the power to extend the original jurisdiction of the Court to "any matter arising under this Constitution or involving its interpretation." 59 Finally and more recently, the Court used Article 75, which attributes to the High Court the original jurisdiction on a series of matters, as a sign of the existence of an "entrenched minimum provision of judicial review." 60

Even with the consolidation of a constitutional practice, however, the Australian legal system still struggles with the concept of constitutional supremacy. In a famous judgement, the High Court stated: "[T]here is no constitutional ground whatever for holding that Federal legislation with respect to matters within federal power cannot affect civil rights, proprietary or others." 61 There is therefore no constitutional obstacle to the limitation of the enjoyment of rights by the sovereign legislator, when it acts according to the procedures provided for in the Constitution. The concept of constitutional supremacy then does not imply that the Constitution is all-powerful in its own polity.

In Canada, the development of constitutional doctrines, after the codification of fundamental rights and the modest influence of the neighbouring American Constitution, have created a different scenario for constitutional supremacy.

The first constitutional text, the Constitution Act of 1867, unified the four initial provinces in the Canadian Dominion. ${ }^{62}$ Over the following century, a series of constitutional instruments

\footnotetext{
${ }^{56}$ D' Emden v Pedder (1904) 1 CLR 91 (Austl.) concerned the Tasmanian Stamp Act addressing legal entities belonging to the federal government. The High Court interpreted the state power of taxation of federal legal entities as a limitation of the constitutional powers of the federal government. The Wollaston case, namely In re The Income Tax Acts (No. 4) (1902) 28 VLR 357 (Austl.), concerned the law of the State of Victoria, which taxed the income of federal government officials. Furthermore, in Wollaston, the Court expressly distinguishes the case from a similar Canadian case, declaring itself free from any influence both of the Canadian Supreme Court case law and the Privy Council. At the same time, the High Court clarified its intention to look to the American model to find a guide in the interpretation of the Constitution, at least in relation to the state-federal government relations.

${ }^{57}$ Austl. Communist Party v Commonwealth (1951) 83 CLR 1, 262-63 (Austl.) (Opinon of Fullagar, J.)

${ }^{58}$ O’Toole v Charles David Proprietary Ltd. (1991) 171 CLR 232, 251 (Austl.) (Opinion of Mason, C.J.).

${ }^{59}$ Id. (Opinion of Dawson, J.).

${ }^{60}$ Plaintiff S157/2002 v Commonwealth (2003) 211 CLR 476, 513 (Austl.) (Opinion of Gleeson, C.J.).

${ }^{61} I d$. at para. 80 .

${ }^{62}$ Constitution Act 1867, 30 \& 31 Vict., c. $3, \$ 56$ (U.K.), reprinted in R.S.C. 1985, app II, no 5 (Can.). The four provinces were Ontario, Québec, Nova Scotia and New Brunswick.
} 
succeeded one another, ${ }^{63}$ leading to the Canada Act of $1982 .{ }^{64}$ The Act includes the Canadian Constitution, a text created through a local constituent process, ${ }^{65}$ and an entrenched Charter of Rights and Freedoms, as well as the recognition of customary and treaty law concerning aboriginal peoples' rights and human rights. In 1988, the Act was patriated through a British parliamentary act that conferred full powers on the federal government of Canada.

Article 52.1 of the Act declares the Constitution to be the "supreme law of Canada" and then specifies that "[a]ny law that is inconsistent with the provisions of the Constitution is, to the extent of the inconsistency, of no force or effect." ${ }^{66}$ So the Canadian Supreme Court justified its power of constitutional adjudication even in the absence of any express constitutional provision. Constitutional adjudication, however, is not really a claim of a brand-new form of judicial authority (a vindicatio potestatis), as was the case in the US. Indeed, constitutional adjudication has been justified on traditional grounds. The Supreme Court pointed out the continuity between judicial scrutiny on the compatibility of Canadian laws with Imperial Instruments, framed under the ultra vires doctrine, and the judicial review of legislation in light of the Constitution and the Charter. ${ }^{67}$ Moreover, the Supreme Court grounded its power of constitutional adjudication on the Canadian Parliament's decision to entrench the Charter in the 1982 Constitution. Therefore, constitutional review in Canada is justified on the ultra vires tradition as well as on a decision of self-limitation of parliamentary sovereignty. ${ }^{6}$

Ultimately, the supremacy of the Canadian Constitution-and therefore its ability to express binding rules of conduct as well as to limit parliamentary sovereignty-rests on its suitability to be applied in combination with a system of principles and values that draws a line of continuity from the British tradition to present times.

Such reasoning mirrors the English sensibility to the principle of parliamentary sovereignty, which is differently celebrated in Canada and Australia. In Australia, the judicial review of legislation originates, to some extent, from the need to protect the federalist principle, rather than from the assertion of constitutional supremacy. In Canada, the limitation of the legislative power in favor of constitutional adjudication has been justified as a choice of self-limitation of the elected representatives of the people. In both cases, constitutional supremacy is the starting point of the reasoning, but it does not imply that the constitution is establishing a legal order ruling out both parliamentary sovereignty and the traditional, pre-constitutional legal culture.

It is even too obvious to stress that constitutional theory in the United States departs from radically different premises when compared to Canadian or Australian constitutional foundations.

\footnotetext{
${ }^{63}$ At least three are worth mentioning: the 1931 Statute of Westminster, which endowed Balfour's declaration on the conditions of the autonomy of the Canadian domain with legal effectiveness; the Letters Patent, issued by the King for the devolution of executive powers to the Governor General of Canada (named for the first time in these terms, without adding the word Dominion); and the Act to Amend the Supreme Court Act, S.C. 1949 (2d sess.), c 37, s 3, which abolished the appeal of the High Court decision before the Privy Council.

${ }^{64}$ Canada Act, 1982, c 11 (U.K.).

${ }^{65}$ Culminating in the agreement between the federal government and nine of the ten provinces, with the exception of Québec, following which the government asked the Parliament of Westminster to adopt a law that would have established the full independence of Canada. Full independence, in the sense of external sovereignty, is however today questioned by those who point out that the Succession to the Throne Act, adopted by the British Parliament in 2013, requires the simple assent of the Canadian Parliament. Some authors argue that a domestic law is required because changes of the rules for the succession to the throne directly affect the domestic legal order. Paul Benoit \& Garry Toffoli, More is Needed to Change the Rules of Succession for Canada, 36 CANAdian PARLIAMENTARy Rev. 10 (2013).

${ }^{66}$ Constitution Act, 1982, $\$ 52(1)$, being Schedule B to the Canada Act, 1982, c 11 (U.K.).

${ }^{67}$ Reference Re B.C. Motor Vehicle Act, [1985] 2 S.C.R. 486 (Can.) (“[I]t is not that [the Charter] has suddenly empowered courts to consider the content of legislation.") (Opinion of Lamer, J.).

${ }^{68} \mathrm{Id}$. at para. 16 (where the Court clarifies that "[i]t was those who extended the scope of constitutional adjudication and entrusted the courts with this new and onerous responsibility. Adjudication under the charter must be approached free of any lingering doubts as to its legitimacy") (Opinion of Lamer, J.).
} 
If we stop for a moment at the concept of constitutional supremacy, however, we find the same resistance to a far-reaching idea of what a constitution is supposed to do.

In the narrative of American independence, ${ }^{69}$ the Constitution represents the act with which the American people normatively constituted themselves by placing the sharing of values and fundamental principles at the heart of their social contract. ${ }^{70}$ In this sense, the Constitution represents the highest form of expression of the sovereignty of the people. "The People" does not exist in a pre-juridical dimension that precedes the Constitution; it is rather constituted in unity at the time of the drafting of the constitutional compact. ${ }^{71}$ Therefore, the American Constitution was immediately endowed with a claim to supremacy over ordinary legislation because the Constitution is both the source of legitimation of the legal system and the effectively superior norm. Indeed, James Madison and Alexander Hamilton considered it "paramount to the government." ${ }^{\prime 2}$ Most importantly, they both identified in the principle of parliamentary supremacy a threat to individual freedoms. The possibility to change the "most fundamental articles of the government" by legislative acts was depicted as a dangerous practice from which legal uncertainty and "alarm" in the votaries would have resulted. ${ }^{73}$ Therefore, freedoms could be secured only by constitutional supremacy.

The original rejection of the principle of parliamentary sovereignty has then allowed constitutional theories of law that are hardly transplantable, without accommodation, in systems of direct English derivation, to develop. Constitutional theories of law refer to those theoretical explanations connecting the supremacy of the Constitution to the need to separate constitutional and ordinary political discourse, with the former shielded from the volubility of parliamentary/ majoritarian will. ${ }^{74}$ There may be different articulations of the precise boundaries between constitutional and ordinary discourse, but American constitutional theories always point at singling out some political and legal options as unquestionable. ${ }^{75}$ Whichever solutions these theories support, the supremacy of the American Constitution is established to shield individual freedoms from the exercise of arbitrary public powers. In this sense, supremacy is not intended to condition the application of any other norms in the legal system, such as those derived from the common law or concerning relationships between private parties. Again, supremacy does not mean the allpowerfulness of the Constitution.

\section{E. The "Gravity" of the Legal Tradition on the Conceptualization of Constitutional Supremacy}

The relevance of the legal tradition on the conceptualization of constitutional supremacy can be appreciated in two perspectives: First, the constitution coexists with a large body of laws that are constitutional either because of their content or because of their ability to integrate the

\footnotetext{
${ }^{69}$ Todd E. Pettys, The Myth of the Written Constitution, 84 Notre Dame L. Rev. 991 (2009).

${ }^{70} 1$ Bruce Ackerman, We The People: Foundations (1993).

${ }^{71}$ The Constitution is the means to keep society's immanent conflict, determined by pluralism of opinions and factions, under control. The Federalist No. 10 (James Madison), No. 1 at 50-51 (Alexander Hamilton).

${ }^{72}$ The Federalist No. 53, at 128 (Alexander Hamilton \& James Madison).

${ }^{73} I d$.

${ }^{74}$ ACKERMAN, supra note 70 , at 3-33.

${ }^{75}$ For Jeremy Waldron, the endurance of a democratic order does not depend exclusively on the existence of a constitutional dimension that draws the limits of the legally possible and the politically questionable. On the contrary, democracy lives in the disagreement between the points of view, which can occasionally be solved by judicial review, without this implying that judicial review, as Dworkin would have argued, improves or optimizes, in any case, the conditions of democratic life. Jeremy Waldron, Law And Disagreement 293-94 (1999). Mark Tushnet challenges the ideological nature of the judicial activity and underlines the need for political confrontation, which he translated in a populist constitutional law, as the place for the emergence of the constitution as the result of the dialectic of the interests. Within this context, the limit of the options available to political confrontation is traced by the so-called thin Constitution, that is, by the Declaration of Independence and the Preamble to the Constitution of 1787. Mark Tushnet, Taking The Constitution Away From The Courts 28 (1999).
} 
constitutional text, and second, the constitution can be, and in fact it is, substantively supplemented, or even subsidised, by the common law.

\section{The Metabolization of the Constitutional Ethos Either in the Form of Pre-Existing Legislation or in That of the Common Law}

Starting from the first one of the above-mentioned perspectives, one can consider Canadian constitutional law.

In Canada, the circumstances of the formation of constitutional law have determined the coexistence between formally and substantially constitutional sources. The inclusion of constitutional sources outside the written constitution is remarkable because, from a formal standpoint, the 1982 Constitution includes only the British North America Act of 1867 and the Canadian Charter of Rights and Freedoms in its list of the acts that comprise the Constitution of Canada. ${ }^{76}$ And yet, much of Canadian constitutional law is to be found in constitutional conventions, intergovernmental agreements, and parliamentary laws with substantially constitutional contents. The latter are statutes adopted by the British Parliament with the aim of constituting the fundamental structures that determine the form of state and government. To these, one should add the so-called quasi-constitutional statutes, endowed with a strengthened normativity, in the sense that they cannot be repealed or modified by ordinary laws. ${ }^{77}$

Unlike what happened within the UK, Canadian scholars seem to have metabolized the problem of identifying constitutional subject matters. There is a general consensus in defining them as those rules, principles, or practices that give form and content to the organization of state powers. ${ }^{78}$ The Supreme Court of Canada has also identified the principles of federalism, democracy, the rule of law, protection of minorities, and the independence of the judiciary as implied constitutional principles by interpreting the provisions of the Constitution Act jointly with the content of substantively constitutional statutes or by drawing on customary constitutional law. ${ }^{79}$

The gravity of the legal tradition on the conceptualization of constitutional supremacy is even clearer if one looks at it from the second perspective and examines the relationship between the constitution and the common law.

In the Australian High Court's decision in Theophanous, ${ }^{80}$ freedom of communication and political speech are both construed by starting from the common law tradition. Such common law-based guarantees, however, are then framed within the constitutional principles governing the organization of state power and parliamentary government. Common law therefore provides the content of the guarantees, and then their constitutional value is attached to their connection to the principle of representative democracy established under the Constitution. Likewise, in the judgement of Cheng v. The Queen, ${ }^{81}$ the High Court construed Section 80 of the Constitution (trial by jury) in light of the Anglo-American legal tradition concerning trials for criminal offences. The High Court refused to give a broad interpretation of the meaning of Section 80 precisely because of the lack of clearly supported arguments at the common law. ${ }^{82}$

\footnotetext{
${ }^{76}$ Constitution Act, 1982, $\$ 52(1)$, being Schedule B to the Canada Act, 1982, c 11 (U.K.).

${ }^{77}$ See, e.g., Ontario Human Rights Comm'n v. Simpson-Sears, [1985] 2 S.C.R. 536, 547 (Can.) (Quasi-constitutional statutes include the Canadian Bill of Rights and the Québec Charter of Rights and Freedoms). See also Vanessa MacDonnell, A Theory of Quasi-Constitutional Legislation, 53 OsGOODE HALL L.J. 508 (2016).

${ }^{78}$ Hugo Cyr \& Monica Popescu, The Supreme Court of Canada, in Comparative Constitutional ReAsoning 156 (András Jakab, Arthur Dyevre, \& Giulio Itzcovich eds., 2017).

${ }^{79}$ See Reference Re Secession of Québec, [1998] 2 S.C.R. 217, paras. 49, 51-54 (Can.).

${ }^{80}$ Theophanous $v$ Herald and Weekly Times (1993) 124 ALR 1 (Austl.).

${ }^{81}$ Cheng $v$ The Queen [2000] HCA 53 (Austl.).

${ }^{82} \mathrm{Id}$. at paras. $57-58$.
} 
The High Court routinely uses the common law to envisage fundamental rights. In doing so, it does not simply make up for a missing bill of rights. In fact, over time, the coexistence of the common law and the Constitution has produced an extension of the material field of constitutional law, which now includes a series of unwritten principles considered to be substantially constitutional. ${ }^{83}$ Moreover, the common law may also play the role of reproaching the executive's violations of human rights law on traditional domestic legal grounds without calling into question international law, even if the outcome is coincidently one of bringing the country back to international standards. In the decision of Plaintiff S297/2013 v. Minister for Immigration and Border Protection \& Anor, the High Court issued a writ of mandamus to order the Minister for Immigration to determine the immigration status of the applicant, a Pakistani refugee. The Court had previously determined the invalidity of the ministerial act that, by fixing the maximum number of temporary visa holders, allowed the Minister to avoid any final determination of the immigrant status of those who applied after the maximum number had been reached. It then used a traditional common law remedy, envisaged under Article 75(v) of the Constitution, to command the executive to cease the indefinite detention of immigrants. ${ }^{84}$

Ultimately, the Constitution works as the structure in which common law guarantees are to be placed. At the same time, it still provides grounds for identifying which common law guarantees deserve to be constitutionally protected from legislative power. In that respect, there is a difference between the Australian High Court's and the UK Supreme Court's approach to common law constitutional rights. In fact, in the Australian context, common law guarantees become constitutional rights because they are framed against the backdrop of the existing constitutional setting. Therefore, the normativity of the written constitution goes hand in hand with customary côté of constitutional law: The concrete functioning of powers, as organized in the Constitution, needs the common law to provide for limitations in light of the guarantees of fundamental rights.

Even in Ireland, where the constitutional order has been founded on the full normativity and supremacy of the 1937 Constitution, the common law plays a crucial role in constitutional reasoning. In People v. O'Shea, ${ }^{85}$ for example, the Supreme Court was called upon to decide whether Article 34, Section 4, Paragraph 3 of the Constitution, which recognizes the right to appeal all judicial decisions, could be modified by the common law principle under which the appeal of the acquittal verdict is never allowed before the Supreme Court. The Court addresses the question as a case of conflict between common law and constitutional provisions. The majority of the Court found that the Constitution must prevail over unwritten law, due to the fact that the adoption of the 1937 Constitution has absorbed the previous customary law, thus imposing a re-reading of it in light of the principles expressly contained within the Constitution. Yet, the judges argue that the constitutional text prevails over the common law only in cases of express constitutional wording. Where normative gaps and/or ambiguities exist, the Constitution is instead permeable and can be the subject of interpretative operations aimed at harmoniously welding the common law, which express a constitutional ethos rooted in the legal culture, to the Constitution of 1937. In this sense, the primacy of the Constitution does not dismiss the customary matrix of that portion of fundamental rights that are not completely covered by the Constitution, but recognized by the common law.

Indeed, the Supreme Court clarified that the body of customary law, judicial decisions, and doctrinal elaborations prior to the Constitution of 1937 must be considered entrenched in the Constitution. It is to be considered repealed only to the extent to which this body conflicts with constitutional provisions. ${ }^{86}$

\footnotetext{
${ }^{83}$ Cheryl Saunders \& Adrienne Stone, The High Court of Australia, in Comparative Constitutional ReAsoning 44 (András Jakab, Arthur Dyevre, \& Giulio Itzcovich eds., 2017).

${ }^{84}$ Plaintiff S297/2013 v Minister for Immigration and Border Prot. \& Anor [2014] HCA 25 (Austl.).

${ }^{85}$ People v. O’Shea [1982] IR 384 (Ir.).

${ }^{86}$ Id. See also Oran Doyle \& Eoan Carolan, The Irish Constitution: Governance And Values (2008).
} 
What is remarkable is that pre-existing legislation does not deserve exactly the same treatment. In the judgment of $A v$. Governor of Arbour Hill Prison, ${ }^{87}$ the High Court clarified that statutes adopted before the 1937 Constitution continue to be valid to the extent that they are not inconsistent with the Constitution or some particular part of it. It means that margins for a declaration of unconstitutionality of statutes are considerably wider when compared to the ones applicable to the common law. Indeed, in the aforementioned People v. O'Shea judgement, the Supreme Court clarified that the constitutional text prevails over the common law only in cases of inconsistencies of the latter with express constitutional wording.

Ultimately, the Constitution does not claim to erase all pre-existing rules and principles. On the contrary, it is claimed to be able to live as much as possible along with the legal tradition of the common law.

In both the Australian and the Irish cases, the supremacy of the constitution is achieved via a certain metabolization of the common law understood as a kind of constitutional ethos.

\section{The Cohabitation of Constitutional Supremacy and the Common Law in the US}

The US needs to be addressed separately, as the cohabitation of constitutional supremacy and the common law is a karstic river that at times emerges in constitutional case law.

In the context of the American Constitution, whose supremacy is not disputed and which is indeed secured by constitutional adjudication, one can simply assume that the legal tradition of the common law is certainly interstitial and almost irrelevant to the justification of the normativity of the Constitution. ${ }^{88}$ Besides, the Supreme Court has consistently rejected the idea that the common law may provide substantive grounds to guide constitutional interpretation. ${ }^{89}$ Yet, there is a recurring argument concerning some form of common law constitutionalism..$^{90}$ Indeed, the common law remains a place in which legal solutions that are alternative to arguments based solely on constitutional principles may be found, even in cases concerning the violation of fundamental rights. It is, in fact, not unusual for the Supreme Court to declare a law unconstitutional by resorting also to a common law ground. In so doing, the Court hooks the interpretation of a constitutional guarantee to a common law rule that is conceptually linked to the constitutional provision at stake. One can take as an example the decision in the case United States $v$. Jones, ${ }^{91}$ in which Justice Scalia delivered the opinion. The case concerned the violation of the right to privacy, protected by the Fourth Amendment, following the placing of a GPS device on a vehicle in the absence of an express warrant. The analysis of the violation of the Fourth Amendment is ordinarily carried out in light of a test elaborated in Katz $v$. United States, concerning the meaning of a reasonable expectation of privacy under the Fourth Amendment. ${ }^{92}$ The application of such a test would have led the Court to face the problem of the existence of an expectation of privacy with respect to a vehicle that moves in public spaces. Instead of tackling this issue, Justice Scalia prefers to resort to common law and, therefore, to assess whether the location of the GPS device can be scrutinized as a case of trespass, a traditional common law rule that safeguards private property from unauthorized intrusion. The guarantees of the Fourth Amendment are therefore protected, in this case, insofar as they are also captured by the legal tradition of the common law. Justice Scalia's argument is alternative to a reasoning that proceeds by exclusively looking at the Constitution. Indeed, Scalia specifies that the standard drawn up

\footnotetext{
${ }^{87}$ A v. Governor of Arbour Hill Prison [2006] 4 IR 95 (Opinion of Laffoy J.) (Ir.) (citing Murphy v. The Attorney General [1982] IR 241 (Opinio of Henchy J.) (Ir.)).

${ }^{88}$ Kent Greenawalt, Statutory and Common Law Interpretation 179 (2012).

${ }^{89}$ Adrian Vermeule, Common Law Constitutionalism and the Limits of Reason, 107 Colum. L. REV. 1482 (2007).

${ }^{90}$ Examples can be traced back to the beginning of the twentieth century. Common law constitutionalism tends to appear regularly in Supreme Court case law. See Cass R. Sunstein, Due Process Traditionalism, 106 Mich. L. Rev. 1543, 1570 (2008).

${ }^{91}$ United States v. Jones, 565 U.S. 400 (2012).

${ }^{92}$ Katz v. United States, 389 U.S. 347 (1967).
} 
in Katz is not substitutive, but alternative to the scrutiny modelled after the trespass analysis. In this way, the Constitution and the common law are contextually construed.

The supremacy of the Constitution thus is combined with common law persistence in constitutional reasoning. Other examples can be traced from the constitutional provision on takings - the so-called takings clause of the Fifth Amendment. Such a provision is integrated by the common law tradition as far as the meaning of fair compensation is concerned. ${ }^{93}$ Moreover, the Supreme Court routinely uses the common law to elucidate the meaning of constitutional provisions concerning criminal law, as the entrenchment of legal solutions within the legal culture is perceived to be particularly relevant in such subject matter. ${ }^{94}$

In either case, the Constitution identifies the legal situations that are protected, and it is then the common law that may provide the precise perimeter of the guarantees.

Moreover, the common law can be useful even when the text of the Constitution fails to provide sufficiently secure guarantees. For example, in the decision Sessions v. Dimaya, ${ }^{95}$ Justice Gorsuch, in his concurring opinion, suggests an interpretation of the Due Process Clause rooted in the English legal tradition, arguing that the clause must be interpreted so as to recognize fundamental guarantees at least equivalent to those offered by the common law. ${ }^{96}$

This attitude is not even distinctively conservative or preordained to achieve conservative results. This is particularly clear if one takes, as an example, the judgement in Obergefell $v$. Hodges. ${ }^{97}$ With that decision, the Supreme Court recognizes the right to same-sex couples' marriage as a fundamental right under the federal Constitution. It does so by applying the Due Process Clause of both the Fourteenth and Fifth Amendments to state officials' conduct of refusing to perform same-sex marriages. The reasoning grounds the fundamentality of such a right on "principles and traditions" of the legal order. This is something more than justifying the recognition of new rights with the usual application of an incremental approach. Indeed, the majority in the Supreme Court injects into the Fifth Amendment, which requires that none shall be deprived of life, liberty, and property without the due process of law, substantive contents, supposedly derived from the traditions of the American polity. So, the term "liberty" includes the freedom to marry the person of one's choice because of the importance of personal freedom and because of the relevance of marriage as the cornerstone of the legal order and as functional to childrearing in American society. This is in an example of common law constitutional interpretation as depicted by David Strauss. ${ }^{98}$

The reference to the legal tradition becomes an instrument for evolving interpretation as much as for achieving conservative results. Indeed, from a doctrinal standpoint, it is noteworthy that even scholars that are worried about the full normativity of the constitutional text, like originalists, concede that the Constitution may leave space to historically entrenched legal solutions. When confronted with the presumed incompatibility between originalism and the doctrine of precedent, some originalist scholars reply with an argument that, at a closer glance, is based on the foundation of the normativity of the written Constitution. They maintain that it is the Constitution itself

\footnotetext{
${ }^{93}$ Richard A. Epstein, Takings: Private Property and the Power of Eminent Domain (1985) (arguing that, on the one hand, the principle of fair compensation in a case of takings expresses the functioning of a legal system governed by the rule of law, and on the other hand, the Constitution illuminates the meaning of the term "property" and, therefore, clarifies which subjective legal positions are worthy of protection, thus limiting judges' discretionary power and the development of the common law).

${ }^{94}$ See, e.g., Apprendi v. New Jersey, 530 U.S. 466 (2000) and Jones v. United States, 526 U.S. 227 (1999) on the Sixth Amendment.

${ }^{95}$ Sessions v. Dimaya, 138 S. Ct. 1204 (2018).

${ }^{96}$ Justice Gorsuch argues that "historical evidence shows that the clause sought to ensure that the people's rights are never any less secure against the governmental invasion than they were at common law." Id. at 1224 .

${ }^{97}$ Obergefell v. Hodges, 135 S. Ct. 2584 (2015).

${ }^{98}$ See David A. Strauss, The Living Constitution 3 (2010) (arguing that "a common law constitution is a 'living' constitution, but it is also one that can protect fundamental principles against transient public opinion").
} 
that allows for precedents to be used because it treats precedents as federal common law that Congress can always override by statutes. ${ }^{99}$ The underpinning of this argument is that a) it is acceptable to apply either the Constitution or precedents and b) the Constitution provides for rules that are normative as a result of the interaction between what it states and the entrenchment of the particular legal solution in the legal tradition. In fact, the use of precedent does not undermine the full normativity of the written text. Rather, the use of precedent is a way to realize it. In other words, the common law functions as a reservoir of principles and rules that may be integrated into the Constitution whenever the text allows it.

There is room to conclude that, despite the centrality and the "holiness" of the written text, the legal community accepts that the constitution expresses rules of conduct that are somehow rooted in the legal tradition rather than simply the product of an absolute prioritization of constitutional imperatives.

\section{F. Conclusion}

Legal traditions shape the practice of legal discourse. Although contemporary globalization processes suggest the need to find the means for dialogue and integration between systems, the relevance of understanding legal discourse within a certain legal family cannot be underestimated. To do so would be to risk preventing dialogue and integration from even starting. This is especially true in constitutional law for at least two reasons.

First, constitutional law is involved in most of the choices concerning global dialogue and supranational integration. Second, constitutional law, at times, backfires in the sense that it is used to support isolationist arguments, grounded in the theorization of some sort of functional equivalence between the supremacy of the constitution and the sovereignty of the nation, understood as independence from any external influence. In some cases, though, what is preserved is not so much the constitution, but the legal tradition.

There is no shortage of examples in both scholarly and political debate. After all, the argument for resisting the use of foreign and international law is largely based on the need to make law an entirely domestic enterprise on the assumption that this would realize the democratic principle at its best. ${ }^{100}$ According to such an understanding, the irrelevance of external sources of law, whether international or foreign, depends on the need to elaborate legal solutions that precisely fit that particular polity. The contextualization of the legal issue, in other words, the conceptual need to identify rights and interests at stake in that specific and culturally-defined polity, is transformed into a territorial isolation of the political community from the others and/or from the international arena. ${ }^{101}$

Simultaneously, the constitutional-ethos-preservationist approach may justify the need for restricting international dialogue to "cultural peers," as seems to be the case for many comparative studies that focus on intra-common law comparison. ${ }^{102}$ It is as if the linguistic and cultural homogeneity guarantees that any comparison would not result in suggesting an alteration of the legal tradition or the constitutional ethos.

\footnotetext{
${ }^{99}$ John O. McGinnis \& Michael B. Rappaport, Originalism and Precedent, 34 Harv. J. L. Pub. Pol. 121-28 (2011). Moreover, according to them, precedents can be followed when the benefit of doing so is greater than the benefit of sticking to the original meaning of the written text.

${ }^{100}$ Antonin Scalia, Scalia Speaks: Reflections on Law, Faith, and Life Well Lived 103 (Christopher J. Scalia \& Edward Whelan eds., 2017).

${ }^{101}$ Reference is made to the debate between Justices Scalia and Breyer as to the purposes of the reference to foreign law in judicial decisions, which has been synthesized by Sujit Choudhry as a new metaphor in comparative constitutional law. See Sujit Choudry, The Migration of CONSTitutional ideas 6 (2009).

${ }^{102}$ Ackerman, supra note 6, at 773 (arguing that "[i]f anything, American practice and theory have moved in the direction of emphatic provincialism").
} 
Finally, the preservationist approach may provide, albeit involuntarily, isolationist agendas with sound legal grounds. One can take as an example the recurrence of arguments concerning common law constitutional rights in English courts' case law. Interestingly enough, the frequency with which these arguments reappeared in courts increased when the UK participation in the ECHR began to be questioned in the political arena. ${ }^{103}$ If the common law provides the political community with guarantees that are equal or even higher than the ones provided by international law, then there is no cultural enrichment in international integration. Rather, the latter can determine an impoverishment of the legal tradition. Therefore, in such a context, the existence of common law constitutional rights may justify arguments about the needlessness of an international bill of rights.

Here comes the relevance of understanding the conceptualization of the supremacy claim of constitutions. Indeed, it is one thing to value the historical, cultural, and traditional dimension of constitutionalism - in other words, the concrete entrenchment of legal solutions in a factually and culturally defined political community - and another to make it the controlling element of constitutional discourse. Grounding the supremacy of constitutions in their ability to express a historically-rooted legal tradition and culture means that legal solutions should always confront the reality of the social context in which they have to be applied. The processes of global interrelation and regional integration belong to this reality and should always be included in the development and evolution of historically grounded legal solutions. There is no inescapable provincialism in a tradition-preserving approach. There is, however, the risk of misrepresenting the need to preserve the polity's legal tradition as the need to shield the polity from external influences, which is, in fact, quite another agenda. In other words, missing the contextual understanding of key concepts in constitutional law may occasionally result in political choices of isolation finding sound explanations within constitutional discourse, particularly in countries that value continuity and conceive constitutional argumentation as a tradition-preserving enterprise. Indeed, the emphasis on legal tradition and culture may lead to principled resistance towards processes of constitutional dialogue and fertilization.

Therefore, global constitutional studies need to deepen their knowledge of the relationship between constitutionalism and legal traditions. Doing so will allow scholars to distinguish, in any cultural and constitutional identity argument, between prejudicially driven positions and authentically sound legal arguments. This Article suggests that a starting point to develop a practice of constitutional argumentation in a global context is the clarification of constitutions' supremacy claims.

\footnotetext{
${ }^{103}$ Alison Young, HRA Howlers: The Conservative Party and Reform of the Human Rights Act 1998, U.K. CONST. L. Ass'N (Oct. 7, 2014), https://ukconstitutionallaw.org/2014/10/07/alison-young-hra-howlers-the-conservative-party-and-reform-ofthe-human-rights-act-1998/.
}

Cite this article: Romeo G (2020). The Conceptualization of Constitutional Supremacy: Global Discourse and Legal Tradition. German Law Journal 21, 904-923. https://doi.org/10.1017/glj.2020.50 